\title{
Understanding the Opportunities of Biofuels for Marine Shipping
}

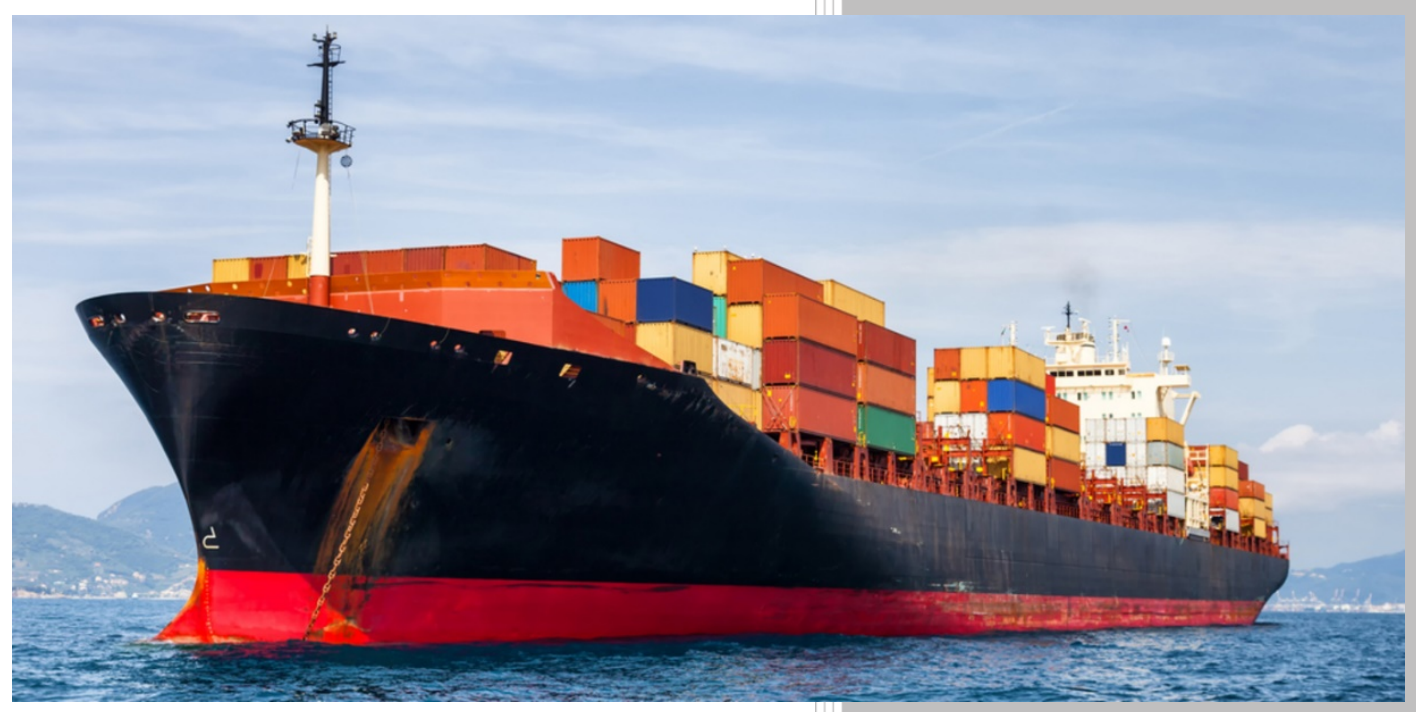

Approved for public release. Distribution is unlimited.
Mike Kass ${ }^{1}$

Zia Abdullah ${ }^{2}$

Mary Biddy ${ }^{2}$

Corinne Drennan ${ }^{3}$

Troy Hawkins ${ }^{4}$

Susanne Jones ${ }^{3}$ Johnathan Holladay ${ }^{3}$

Doug Longman ${ }^{4}$

Emily Newes ${ }^{3}$

Tim Theiss ${ }^{1}$

Tom Thompson 5

Michael Wang ${ }^{4}$

${ }^{1}$ Oak Ridge National Laboratory ${ }^{2}$ National Renewable Energy Laboratory

${ }^{3}$ Pacific Northwest National Laboratory

${ }^{4}$ Argonne National Laboratory

${ }^{5}$ US Maritime Administration

December 2018 


\title{
DOCUMENT AVAILABILITY
}

Reports produced after January 1, 1996, are generally available free via US Department of Energy (DOE) SciTech Connect.

Website www.osti.gov

Reports produced before January 1, 1996, may be purchased by members of the public from the following source:

\author{
National Technical Information Service \\ 5285 Port Royal Road \\ Springfield, VA 22161 \\ Telephone 703-605-6000 (1-800-553-6847) \\ TDD 703-487-4639 \\ Fax 703-605-6900 \\ E-mail info@ntis.gov \\ Website http://classic.ntis.gov/
}

Reports are available to DOE employees, DOE contractors, Energy Technology Data Exchange representatives, and International Nuclear Information System representatives from the following source:

Office of Scientific and Technical Information

PO Box 62

Oak Ridge, TN 37831

Telephone 865-576-8401

Fax 865-576-5728

E-mail reports@osti.gov

Website http://www.osti.gov/contact.html

This report was prepared as an account of work sponsored by an agency of the United States Government. Neither the United States Government nor any agency thereof, nor any of their employees, makes any warranty, express or implied, or assumes any legal liability or responsibility for the accuracy, completeness, or usefulness of any information, apparatus, product, or process disclosed, or represents that its use would not infringe privately owned rights. Reference herein to any specific commercial product, process, or service by trade name, trademark, manufacturer, or otherwise, does not necessarily constitute or imply its endorsement, recommendation, or favoring by the United States Government or any agency thereof. The views and opinions of authors expressed herein do not necessarily state or reflect those of the United States Government or any agency thereof. 
Energy and Transportation Science Division

\title{
UNDERSTANDING THE OPPORTUNITIESOF BIOFUELS FOR MARINE SHIPPING
}

\author{
Mike Kass ${ }^{1}$ \\ Zia Abdullah ${ }^{2}$ \\ Mary Biddy ${ }^{2}$ \\ Corinne Drennan ${ }^{3}$ \\ Troy Hawkins ${ }^{4}$ \\ Susanne Jones ${ }^{3}$ \\ Johnathan Holladay ${ }^{3}$ \\ Doug Longman ${ }^{4}$ \\ Emily Newes ${ }^{2}$ \\ Tim Theiss ${ }^{1}$ \\ Tom Thompson ${ }^{5}$ \\ Michael Wang ${ }^{4}$ \\ ${ }^{1}$ Oak Ridge National Laboratory \\ ${ }^{2}$ National Renewable Energy Laboratory \\ ${ }^{3}$ Pacific Northwest National Laboratory \\ ${ }^{4}$ Argonne National Laboratory \\ ${ }^{5}$ U.S. Maritime Administration
}

December 2018

Prepared by

OAK RIDGE NATIONAL LABORATORY

Oak Ridge, TN 37831-6283

managed by

UT-BATTELLE LLC

for the

US DEPARTMENT OF ENERGY

under contract DE-AC05-00OR22725 



\section{CONTENTS}

Page

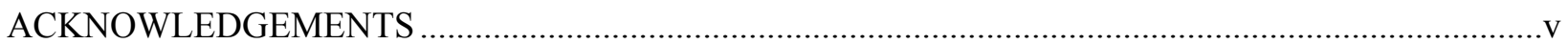

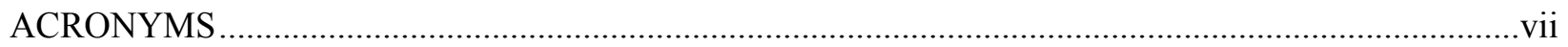

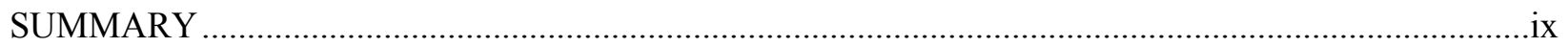

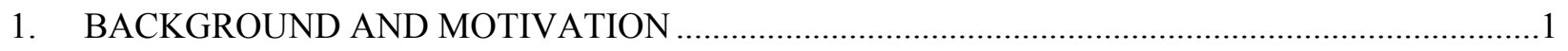

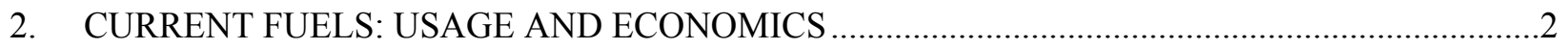

3. ENVIRONMENTAL CONSIDERATIONS, IMPENDING REGULATIONS, CHANGING

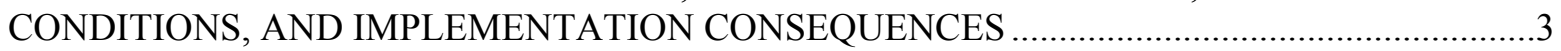

4. AVAILABLE FUEL OPTIONS AND THEIR RELATIVE ECONOMICS, IMPLEMENTATION INFRASTRUCTURE, AND TIMELINE ..................................................

4.1 LOW-SULFUR RESIDUAL FUEL (LOW-SULFUR FUEL OIL) ........................................

4.2 LOW-SULFUR DISTILLATES: MARINE GAS OIL AND MARINE DIESEL OIL ..............4

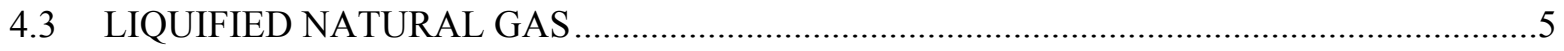

4.4 EXHAUST GAS CLEANING SYSTEMS ( $\mathrm{SO}_{\mathrm{x}}$ SCRUBBERS) …......................................

5. CHARACTERISTICS OF MARINE BIOFUELS AND THE SPECIFICATIONS FOR

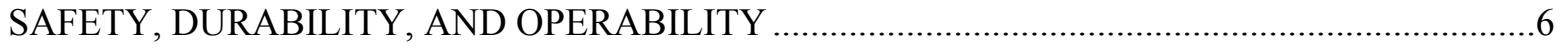

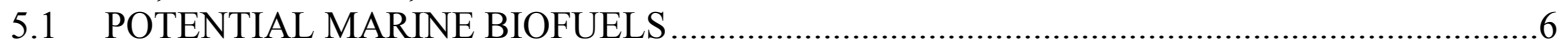

5.2 BIOFUELS AS SUBSTITUTES FOR PETROLEUM MARINE FUELS MGO AND

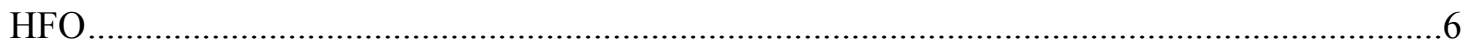

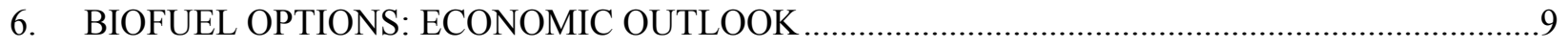

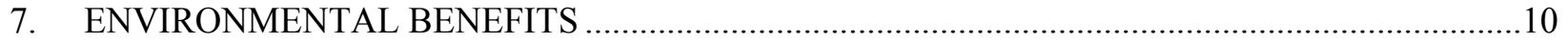

8. R\&D CHALLENGES, OPPORTUNITIES, AND RECOMMENDATIONS ASSOCIATED WITH BIOFUELS, ESPECIALLY BIO-OIL AS A MARINE FUEL ….....................................12

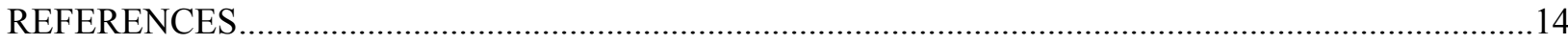





\section{ACKNOWLEDGEMENTS}

The work described herein was sponsored by the US Department of Energy (DOE) Bioenergy

Technologies Office. The authors gratefully acknowledge the support and guidance of Zia Haq, Mohan Gupta, and Seth Menter at DOE. This paper also benefitted from discussions with Steve Walker and John Larese from ExxonMobil. 



\section{ACRONYMS}

ASTM

$\mathrm{CO}_{2}$

ECA

EEDI

EPA

FP

F-T

GHG

HFO

HTL

IMO

LNG

MDO

MGO

$\mathrm{NO}_{\mathrm{x}}$

$\mathrm{PM}$

$\mathrm{SO}_{\mathrm{x}}$

SVO
ASTM International (formerly the American Society for Testing and Materials) carbon dioxide

emission control area

energy efficiency design index

US Environmental Protection Agency

fast-pyrolysis

Fischer-Tropsch

greenhouse gas

heavy fuel oil

hydrothermal liquefaction

International Maritime Organization

liquified natural gas

marine diesel oil

marine gas oil

nitrogen oxide

particulate matter

sulfur oxide

straight vegetable oil 



\section{SUMMARY}

This report examines the potential benefits, feasibility, and barriers to the use of biofuels in place of heavy fuel oil (HFO) and marine gas oil for marine vessels. More than $90 \%$ of world's shipped goods travel by marine cargo vessels powered by internal combustion (diesel) engines using primarily low-cost residual HFO, which is high in sulfur content. Recognizing that marine shipping is the largest source of anthropogenic sulfur emissions and is a significant source of other pollutants including particulates, nitrogen oxides, and carbon dioxide $\left(\mathrm{CO}_{2}\right)$, the International Maritime Organization enacted regulations to lower the fuel sulfur content from $3.5 \mathrm{wt} . \%$ to $0.5 \mathrm{wt} . \%$ in 2020 . These regulations require ship operators either to use higher-cost, low-sulfur HFO or to seek other alternatives for reducing sulfur emissions (i.e., scrubbers, natural gas, distillates, and/or biofuels). The near-term options for shipowners to comply with regulations include fueling with low-sulfur HFO or distillate fuels or installing emissions control systems. However, few refineries are equipped to produce low-sulfur HFO. Likewise, the current production rates of distillates do not allow the necessary expansion required to fuel the world fleet of shipping vessels (which consume around 330 million metric tons). This quantity is more than twice that used in the United States for cars and trucks. The other near-term option is to install emission control systems, which also requires a significant investment. All of these options significantly increase operational costs. Because of such costs, biofuels have become an attractive alternative since they are inherently low in sulfur and potentially also offer greenhouse gas benefits. Based on this preliminary assessment, replacing HFO in large marine vessels with minimally processed, heavy biofuels appears to have potential as a path to reduced emissions of sulfur, $\mathrm{CO}_{2}$, and criteria emissions. Realizing this opportunity will require deeper knowledge of (1) the combustion characteristics of biofuels in marine applications, (2) their compatibility for blending with conventional marine fuels (including HFO), (3) needs and costs for scaling up production and use, and (4) a systems assessment of their life cycle environmental impacts and costs. It is recommended that a research program investigating each of these aspects be undertaken to better assess the efficacy of biofuels for marine use. 



\section{BACKGROUND AND MOTIVATION}

The marine shipping sector is one of the largest consumers of petroleum fuels and, consequently, one of the largest emitters of air pollutants. Global marine fuel consumption is estimated to be $\sim 330$ million metric tons ( 87 billion gallons) annually. This quantity exceeds that used in aviation and is more than twice the amount of diesel fuel used by medium- and heavy-duty vehicles to move freight in the United States. More than $90 \%$ of world's shipped goods travel by marine cargo vessels, which are powered primarily with heavy fuel oil (HFO). HFO is also used to power cruise liners and some fishing and service vessels. HFO is a low-value fuel composed of the residuum left over from the distillation of crude oil into higher value products. As such, it contains high-sulfur levels, which are released to the atmosphere following combustion in the medium and high-speed engines used in oceanic transport as well as the large slow-speed engines used to power marine cargo vessels. In the United States, these vessels average well over 20,000 ports of call every year. Marine shipping is the largest source of anthropogenic sulfur oxide (SOx) emissions in the world and is the primary source of black carbon in the arctic [IMO 2015]. For cities with large ports, marine emissions are significant contributors to nitrogen oxide (NOx) and particulate matter (PM). The overall demand for marine fuels is expected to double by 2030 [Pearce 2009, Walker 2017], and this increase presents a serious pollution and health risk.

The marine industry is facing several challenges related to emission regulations. The International Maritime Organization (IMO), the international governing agency under the United Nations for international marine operations, has set aggressive fuel quality requirements for emission targets to reduce global marine fuel sulfur content from the current $3.5 \%$ to $0.5 \%$ by weight in 2020 . The sulfur limit is further reduced to $0.1 \%$ for ships operating in coastal regions of the United States and northern Europe (known as emission control areas or ECAs). By comparison, on-highway diesel fuel has a sulfur limit of $15 \mathrm{ppm}$, or $0.0015 \%$. Compulsory reductions in sulfur content has required ship operators to shift their engines from lower cost HFO to much costlier distillate fuels, such as marine diesel oil (MDO) and lowsulfur distillate marine gas oil (MGO) when operating in ECAs. In addition, the marine industry is under pressure to reduce its carbon intensity through improvements in efficiency. Beyond 2025, IMO has established a framework for reducing carbon dioxide $\left(\mathrm{CO}_{2}\right)$ emissions per metric ton-mile by $30 \%$ for new ships [IMO 2016]. The IMO emission targets are moving the marine industry to aggressively seek fuel alternatives with lowered sulfur content and lower $\mathrm{CO}_{2}$ emissions [Wiesmann 2010]. These alternatives include expanded use of distillates, liquified natural gas (LNG), and biomass-derived fuels (biofuels) as HFO substitutes. It is important to note that this regulation does permit high-sulfur HFO use if $\mathrm{SO}_{\mathrm{x}}$ reduction technologies (scrubbers) are employed to mitigate $\mathrm{SO}_{\mathrm{x}}$ emissions. Among these approaches, biofuels are of interest because they provide a potential pathway towards key emissions reductions, improved energy security, and reductions in the carbon intensity of marine shipping.

The purpose of this report is to assess the potential of biofuel — especially bio-oil and bio-crudealternatives to marine residual fuels. Bio-oils contain high levels of oxygenates (relative to conventional hydrocarbon fuels) and therefore must be upgraded at significant cost for use as a drop-in additive for distillates such as on-road diesel fuel. However, the potential for blends with HFO is promising in scenarios where requirements for cetane number, oxygen, aromaticity, and other properties are much less rigorous. Biofuels offer potential synergistic benefits when blended with HFO by reducing sulfur content, improving overall lubricity, and offering potentially lower ash and emission profiles, especially for PM and SOx. As renewable fuels, they also offer the potential to reduce life-cycle $\mathrm{CO}_{2}$ for marine operations. However, because numerous uncertainties remain, there is a need for further evaluation, including the overall compatibility of bio-oils with marine engine combustion and fuel systems and the potential need to remove water (bio-oils are often hydrophilic). Key to establishing feasibility is determining whether an economic and environmental argument exists for biofuel (or bio-oil) use in marine applications as a 
substitute for HFO and/or distillate fuels. This report highlights the research needs and potential associated with marine biofuels.

\section{CURRENT FUELS: USAGE AND ECONOMICS}

Marine ships generally use three types of fuels: HFO, MGO, and MDO. The estimated quantities used to power marine vessels are shown in Table 1, along with the estimated costs as of September 2018. The only standard for these fuels for marine engine use is ISO 8217, which has separate specifications on marine distillates, marine residuals. and biodiesel additions. ASTM International (ASTM) has also set standards for pyrolysis liquid biofuels used in burners and boilers (ASTM D7544). However, many of the compatibility criteria and tests are also appropriate for marine applications. As shown in the table, HFO accounts for more than $75 \%$ of the fuel used by all marine vessel types.

Table 1. Primary marine fuels and their estimated annual consumption and costs

\begin{tabular}{lccc}
\hline \multirow{2}{*}{ Marine fuel type } & $\begin{array}{c}\text { Estimated quantity } \\
\text { consumed (metric ton/year) }\end{array}$ & \multicolumn{2}{c}{ Estimated cost [DNV GL 2018] } \\
\cline { 3 - 4 } & [BP 2017] & & (\$\$ \$ $/$ gallon) \\
\hline HFO (residual fuel) & 250 & 460 & 1.72 \\
MGO (distillate fuel) & 10 & 700 & 2.62 \\
MDO (MGO/HFO blend) & 70 & $\sim 700$ & $\sim 2.62$ \\
\hline
\end{tabular}

HFO is part of the tar-like residuum that is left over following distillation and subsequent cracking of crude to produce lighter hydrocarbon products, such as distillate diesel fuels and gasoline. As a residual fuel, it is relatively inexpensive and, as shown in Table 1 , is typically around $65 \%$ of the cost of distillate fuels.

In addition to sulfur, HFO also contains high concentrations of water and solid impurities that must be removed before combustion in the engine and boilers. The high viscosity of HFO necessitates that it be heated to achieve the proper rheology for engine use and to enable settling of heavier (less desired) constituents in tank systems. Heating is achieved via superheated steam produced by onboard boilers, which are also fueled with HFO. A centrifuge system separates the water and solids (sludge) before combustion. These wastes are stored onboard before being disposed of in port. The sludge component has some value associated with reclaiming the oil fraction; therefore, a sludge treatment company will pay the shipowner for the sludge, with the price determined by composition. Consequently, although sludge storage and management onboard are costs borne by ship operators, waste sludge disposal is not an additional cost.

MGO is composed of lighter distillates and is similar to diesel fuel in chemistry (except for 100 times more sulfur) and cost. As such, it does not require onboard heating, separation, or waste disposal. MGO is used predominantly in coastal ECAs to meet fuel sulfur and emission requirements. On the other hand, $\mathrm{MDO}$ is a blend of MGO and HFO and has intermediate physical properties between its blend components. Here, cost depends on the blend ratio, but since MDO is primarily MGO, its price is comparable. The HFO component necessitates heating and separation, the degree of which depends on blend level. The higher cost of MGO and MDO preclude their use in oceanic transport, where HFO is the overwhelming choice because of its much lower cost. Even with the added costs associated with fuel heating, handling, and storage, HFO is a more economical option. 


\section{ENVIRONMENTAL CONSIDERATIONS, IMPENDING REGULATIONS, CHANGING CONDITIONS, AND IMPLEMENTATION CONSEQUENCES}

Federal and state agencies have been regulating harmful exhaust emissions from the transportation sector since the 1960s. These regulations govern the emissions of $\mathrm{NO}_{\mathrm{x}}, \mathrm{PM}$, carbon monoxide, unburned hydrocarbons, and $\mathrm{CO}_{2}$ associated with terrestrial transport and stationary power. Regulation of the marine sector is much more recent, with the initial focus being the reduction of sulfur emissions in coastal areas. In addition to being the primary source of black carbon in the arctic [IMO 2015], marine shipping also accounts for $2.3 \%$ of world $\mathrm{CO}_{2}$ emissions.

To control and minimize air pollution, the IMO has identified $\mathrm{CO}_{2}, \mathrm{SO}_{\mathrm{x}}$, and $\mathrm{NO}_{\mathrm{x}}$ as major pollutants, and it is expected that PM will soon be added to this list. The IMO has issued new rules that steeply cut the global limit on the sulfur content of marine fuel from $3.5 \%$ to $0.5 \%$ starting January 1,2020 . This decision follows several other marine fuel regulations that limit sulfur content, such as the implementation of ECAs in coastal waters and specific sea lanes, which limited the maximum sulfur content of fuels to $0.1 \%$ by weight starting July 2015 . Perhaps more dramatic for the longer term, the IMO agreed in April 2018 to cut carbon emissions from ships by at least $50 \%$ by 2050 compared with 2008 levels - an absolute target for emission reductions for an entire industry.

Shipowners have several options for meeting the sulfur limits within an ECA and in all locations after 2020. Today, about 13 countries produce more than $60 \%$ of the HFO in use [Larese 2018]. It is expected that many of the refineries in these countries will develop residual fuel oils with low-sulfur content; however, a significant number have not made the necessary modifications to do so. Low-sulfur HFO will likely be more expensive than the high-sulfur fuel (at least in the short term) because of the added cost of process modifications. An even more expensive option would be to switch to MGO or, more likely, a blend of MGO and high-sulfur HFO to achieve $0.5 \%$ sulfur fuel. Switching to MGO will lead to increased shipping costs and could increase the demand and cost for conventional diesel fuel. Since the turn of the twenty-first century, most high-sulfur fuel has been consumed by the shipping industry because of the environmental restrictions. The current historic demand for low-sulfur fuel combined with the equally historic need to disposition unwanted high-sulfur fuel oil will make it challenging for shipowners to obtain acceptable fuel at economical prices. Scrubbers and other alternate fuels might be a viable investment to meet the challenge, the conversions being significant investment decisions in a market with fluctuating prices for various fuel options.

The global sulfur cap is meaningless if it is not enforced. Noncompliance is possible, but the US Environmental Protection Agency (EPA) and the US Coast Guard are committed to working together on both compliance and enforcement with heavy fines and seizure of noncompliant vessels. Although the IMO has not established any fines or sanctions, all the key shipping organizations have stated that their members will comply with the new regulation.

Another area of new regulation is $\mathrm{CO}_{2}$ emissions. To control and limit $\mathrm{CO}_{2}$, the IMO has established the energy efficieny design index (EEDI) as a regulatory parameter to improve the energy efficiency of large ships and mandates an increasingly stringent EEDI score for the majority of new vessels [ICCT 2011]. The regulation requires most new ships to be $10 \%$ more efficient beginning in $2015,20 \%$ more efficient by 2020 , and $30 \%$ more efficient by 2025 . Meeting the EEDI targets will increase capital and implementation costs, which are expected to be offset by projected savings of up to 75 million tons of fuel and \$52B annually. This regulation applies to new cargo ships of more than 400 gross tons and varies with ship type, size, and function. The internal combustion engines on large vessels are already among the most efficient prime movers in existence, so the EEDI targets will have to be met mostly with new, improved ship designs and the implementation of more efficient onboard systems. It is expected that even further EEDI targets will be forthcoming, which will necessitate consideration of alternative fuels and 
more system-level design features and integration strategies. Currently, the regulation includes oil and gas tankers, bulk carriers, general cargo ships, cargo carriers, and container ships. These ships account for $72 \%$ of $\mathrm{CO}_{2}$ emissions from the new-build fleet.

\section{AVAILABLE FUEL OPTIONS AND THEIR RELATIVE ECONOMICS, IMPLEMENTATION INFRASTRUCTURE, AND TIMELINE}

The IMO regulations for sulfur reduction cover all types of vessels, but only those operating on HFO will have to implement fueling or hardware changes. The impact of these standards on refinery economics and cost to ship operators has been explored by a number of government and private-sector organizations including the EPA, IHS, and Platts, [EPA 2009, IHS 2017, Platts 2016]. Ship owners and operators have two foreseeable alternatives to consider. They can either switch to low-sulfur fuels or implement scrubber technologies to mitigate sulfur emissions. Low-sulfur fuels can be further categorized into low-sulfur HFO, distillate fuel (MGO and MDO), LNG, and biofuels. The choice of adoption is highly dependent on the specific vessel owner's economic considerations. The impact of regulations and options on ports and port authorities is less understood and is a subject for further study. Clearly, options such as expanded LNG use will entail significant infrastructure cost to allow for fueling as well as modifications to facilitate loading/unloading of cargo.

\subsection{LOW-SULFUR RESIDUAL FUEL (LOW-SULFUR FUEL OIL)}

The quality of the HFO being produced depends on the quality of the crude being refined and on the processes used. HFO quality is highly variable and is usually tested before procurement by the ship operator. To recover the capital and operational expense associated with low-sulfur HFO production, refineries will need to sell low-sulfur HFO at higher costs. Furthermore, increased demand for low-sulfur HFO in the near-term will also drive up cost. Ultimately, the consumer will have to pay more for goods that are shipped overseas. Because not all refineries are equipped to produce low-sulfur HFO, some will likely still market high-sulfur HFO with the expectation that enforcement will not occur in some locations and that scrubber technologies will be implemented by shipowners to achieve emission targets. One possible consequence is that the demand and cost of high-sulfur HFO decreases. A drop in the price of high-sulfur HFO could favor the adoption of sulfur scrubbers. Consequently, the lower fuel cost could compensate for the added expense of equipping a ship with a sulfur scrubber system.

\subsection{LOW-SULFUR DISTILLATES: MARINE GAS OIL AND MARINE DIESEL OIL}

Merchant ships that normally use HFO fuel switch operation to MGO or MDO when in ECA localities. Their engines and fuel systems are fully compatible with these distillate fuels. However, as shown in Table 1, the cost of MGO and MDO is higher than HFO. Additionally, many refineries are not currently designed to expand production of distillates (including diesel and aviation fuels). However, projections by ExxonMobil show that the world demand for distillate fuels is expected to grow by $55 \%$ by 2040 [ExxonMobil 2017]. These projections assume that low-sulfur regulations will be met by LNG and therefore do not include increased distillate demand by the marine sector in response to regulations. These factors - limited supply and increased competition - could dramatically increase the cost of diesel prices worldwide. Because the supply of distillate fuels is limited, one potential consequence of an increased demand for MGO is increased diesel fuel prices worldwide. 


\subsection{LIQUIFIED NATURAL GAS}

Retrofitting existing vessels or building new vessels with the capability to use LNG is another option that has been widely discussed. The challenges associated with LNG are (1) the added costs of LNG storage infrastructure, (2) limited range due to the lower energy content of LNG relative to residual and distillate fuels, and (3) reduced carrying capacity due to the requirement that LNG tanks must be above deck (see Figure 1). However, relatively low LNG prices are expected to help improve the economic challenges. Another key factor that could limit the adoption of LNG-fueled vessels is the currently limited infrastructure for LNG supply and distribution for use in marine vessels. Expanding the infrastructure will come at a price and will influence the overall cost of LNG options, although increasing global trade of natural gas and the associated infrastructure could help offset a portion of this cost. Based on IHS estimates, as of early 2017 only 10 LNG vessels had entered the market [IHS 2017]; however, 9 LNG cargo vessels are under construction in China, and 6 more are under construction in other countries. The on-deck LNG storage requirement not only limits cargo space but also imparts challenges for loading and offloading. LNG use and efficiency would be greatly facilitated with the approval of below-deck storage.

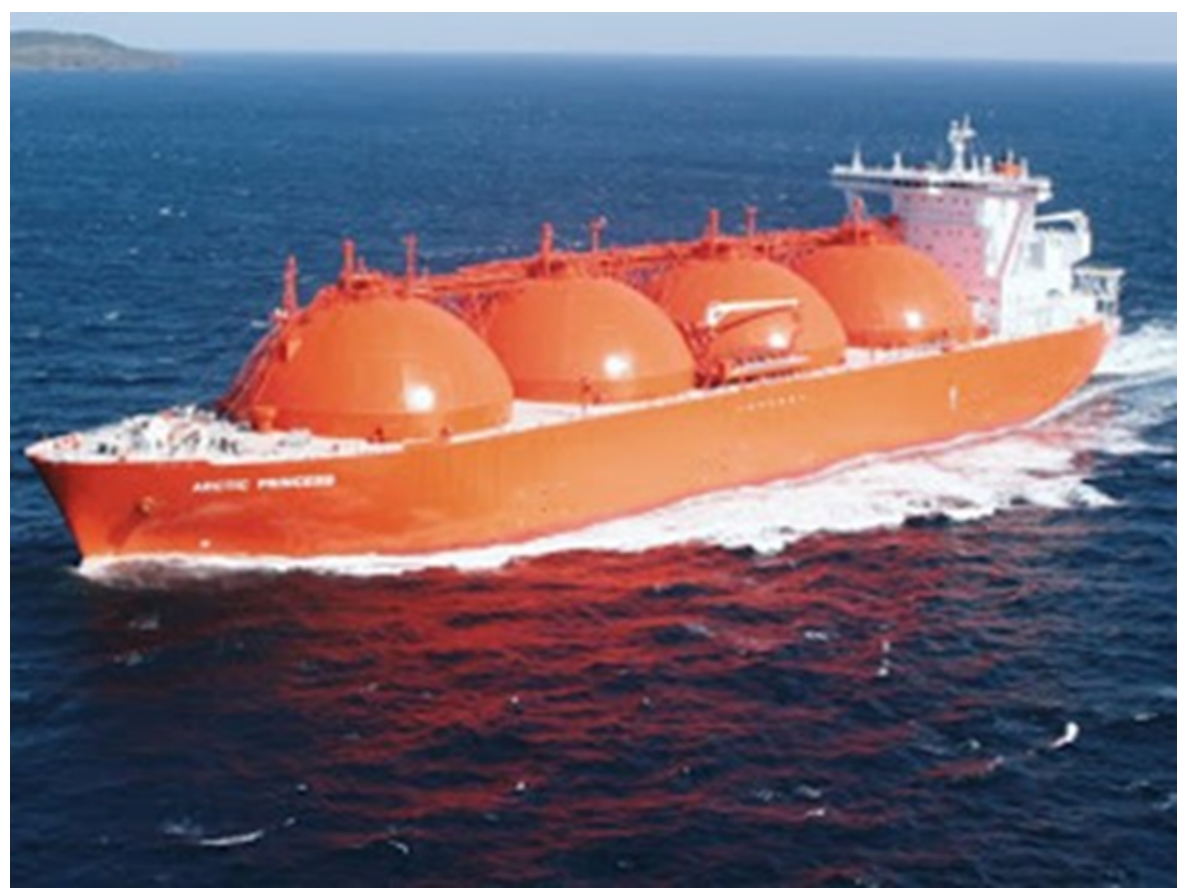

Figure 1. Photograph of an LNG cargo vessel. Note that the LNG is stored in large tanks on deck. Photo is licensed under CC BY-SA.

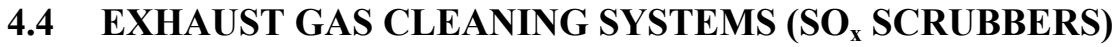

Based on IHS estimates of the 120,000 ships in the global fleet, about 30,000 operate on HFO. The IHS has projected that these ships will be the vessels most likely to comply with the IMO regulations by installing scrubber systems. At the time of recent reports, only roughly 300 ships have installed such systems and installation is expected to be delayed in many ships until closer to the 2020 compliance date. However, installation of these scrubber systems might be stalled as there is expected to be a capacity limit of 3,000 ships that can be retrofitted each year. The determination by vessel owners to install such systems is highly dependent on the projected cost differential between the $0.5 \%$ and $3.5 \%$ sulfur content fuels. Depending on the projected cost difference of these fuels, the payback period associated with these traditionally $\$ 3-5 \mathrm{M}$ investments for the onboard scrubber systems has been estimated to range from a few years to more than 10 years [IHS 2017, Platts 2016]. Note that the majority of scrubbers being installed 
are open-loop designs that discharge the accumulated sulfur to the ocean. These systems are not allowed in ECAs, and their use is limited to open-sea operation only.

\section{CHARACTERISTICS OF MARINE BIOFUELS AND THE SPECIFICATIONS FOR SAFETY, DURABILITY, AND OPERABILITY}

Biofuels offer potential synergistic benefits when blended with petroleum fuels by reducing sulfur content and by offering potentially lower ash and emission profiles. Depending on the biomass feedstock and processing conditions, biofuels can be low in sulfur and nitrogen while also providing a low carbon intensity.

\subsection{POTENTIAL MARINE BIOFUELS}

Biofuel candidates include (1) oxygenated biofuels, such as straight vegetable oil (SVO), biodiesel, fastpyrolysis (FP) bio-oil, and hydrothermal liquefaction (HTL) biocrude, and (2) hydrocarbon biofuels, which include renewable diesel, Fischer-Tropsch (F-T) diesel, and fully upgraded (deoxygenated) bio-oil, and biocrude. A listing of these biofuel types, characteristics, and properties is shown in Tables 2 and 3. Each candidate has differing properties that will dictate which type of marine fuels it can be blended with, displace, or partially displace. However, they all have exceptionally low levels of sulfur. Oxygenated biofuels have lower energy densities than liquid hydrocarbon fuels; however, the bound oxygen atoms act as oxidizers to reduce PM formation during combustion. Of the nonoxygenated hydrocarbon biofuels, hydrotreated FP and HTL derived bio-oils/biocrudes are wider boiling than conventional diesel and might require fractionation depending upon use. However, there remains significant uncertainty in quality requirements and the need for further evaluation of blending biofuels, such as the potential need to remove water (as oxygenated fuels can be hydrophilic in nature) or any residual solids.

\subsection{BIOFUELS AS SUBSTITUTES FOR PETROLEUM MARINE FUELS MGO AND HFO}

A selected list of key properties for marine fuels is shown in Table 4. Of the biofuels described in Section 5.1, only biodiesel, F-T diesel, renewable diesel, and upgraded bio-oil are miscible with marine distillate fuels. Currently only biodiesel (at concentrations of up to 7 vol.\%) is approved for use with MGO as a marine fuel, and studies by ExxonMobil, MARAD, and others have shown significant PM reductions when biodiesel is blended into MGO [Larese 2018]. PM reduction is an immediate environmental benefit of oxygenated fuels, and often significant reductions can be achieved at relatively low blend levels $(<10 \%)$. Since bio-oils cannot be directly mixed with distillates, any attempt to integrate bio-oil with MGO will necessitate the use of surfactants to create an emulsified fuel mixture. Emulsified fuels, even when they exist as microemulsions, are prone to separation over time and, therefore, typically have low shelf lives. The impact of the entrained water within bio-oil on the combustion process is unknown. However, water addition to combustion is a known pathway towards reducing PM emissions and, in some instances, NOx emissions as well. The straight replacement of MGO with a biofuel necessitates that the production volume of biofuel be high enough to meet the usage needs. It is not clear whether existing biofuel production can effectively displace MGO. However, as blends, biofuels offer opportunities towards both $\mathrm{PM}$ and $\mathrm{CO}_{2}$ reduction; and as the demand for MGO increases, biofuels could offer an economic incentive as well. 
Table 2. Key characteristics of marine biofuel blendstocks

\begin{tabular}{|c|c|c|c|c|c|}
\hline Fuel type & Feedstock & Availability & Advantages & Disadvantages & $\begin{array}{l}\text { US production } \\
\text { and status }\end{array}$ \\
\hline $\begin{array}{l}\text { Biodiesel or } \\
\text { fatty acid } \\
\text { methyl esters }\end{array}$ & $\begin{array}{l}\text { Vegetable } \\
\text { oil and } \\
\text { animal fats }\end{array}$ & Commercial & $\begin{array}{l}\text { 1. Miscible with } \\
\text { MGO } \\
\text { 2. Mature } \\
\text { technology } \\
\text { 3. Approved for use } \\
\text { with MGO (7\% } \\
\text { blend level) }\end{array}$ & $\begin{array}{l}\text { Oxidation stability } \\
\text { and shelf life }\end{array}$ & $\begin{array}{l}1,568 \mathrm{~mm} \\
\text { gal/year } \\
\text { (EIA 2017) }\end{array}$ \\
\hline SVO & $\begin{array}{l}\text { Vegetable } \\
\text { oils }\end{array}$ & $\begin{array}{l}\text { Commercial } \\
\text { but research } \\
\text { needed for } \\
\text { marine use }\end{array}$ & $\begin{array}{l}\text { Relatively } \\
\text { inexpensive }\end{array}$ & $\begin{array}{l}\text { Oxidation stability } \\
\text { and shelf life }\end{array}$ & \\
\hline $\begin{array}{l}\text { Renewable } \\
\text { diesel }\end{array}$ & $\begin{array}{l}\text { Vegetable } \\
\text { oils, and } \\
\text { animal fats }\end{array}$ & Commercial & $\begin{array}{l}\text { 1. Miscible with } \\
\text { MGO } \\
\text { 2. Mature } \\
\text { technology } \\
\text { 3. Excellent } \\
\text { combustion } \\
\text { properties } \\
\text { 4. Near zero } \mathrm{O}_{2}\end{array}$ & $\begin{array}{l}\text { High production } \\
\text { costs }\end{array}$ & $350 \mathrm{~mm}$ gal/year \\
\hline F-T diesel & $\begin{array}{l}\text { Woody and } \\
\text { other } \\
\text { biomass }\end{array}$ & $\begin{array}{l}\text { Commercial, } \\
\text { not currently } \\
\text { from biomass }\end{array}$ & $\begin{array}{l}\text { 1. Miscible with } \\
\text { MGO } \\
\text { 2. Excellent } \\
\text { combustion } \\
\text { properties }\end{array}$ & $\begin{array}{l}\text { Complex } \\
\text { processing and } \\
\text { expensive }\end{array}$ & $\begin{array}{l}\text { Production sites } \\
\text { under } \\
\text { construction }\end{array}$ \\
\hline FP bio-oil & $\begin{array}{l}\text { Woody and } \\
\text { other } \\
\text { biomass }\end{array}$ & Commercial & $\begin{array}{l}\text { 1. Possible low PM } \\
\text { formation } \\
\text { 2. Miscible with } \\
\text { butanol and } \\
\text { butanol blends }\end{array}$ & $\begin{array}{l}\text { 1. Incompatibiliti } \\
\text { es with } \\
\text { infrastructure } \\
\text { 2. Not miscible } \\
\text { with neat MGO }\end{array}$ & $\begin{array}{l}\text { Commercial } \\
\text { production } \\
(13 \mathrm{~mm} \text { gal } \\
\text { Canada; \% mm } \\
\text { gal/year US) }\end{array}$ \\
\hline $\begin{array}{l}\text { HTL } \\
\text { biocrude }\end{array}$ & $\begin{array}{l}\text { Woody and } \\
\text { other } \\
\text { biomass }\end{array}$ & Research stage & $\begin{array}{l}\text { Improved heating } \\
\text { value compared } \\
\text { with FP bio-oil } \\
\end{array}$ & $\begin{array}{l}\text { Demonstration } \\
\text { scale only }\end{array}$ & \\
\hline $\begin{array}{l}\text { Upgraded FP } \\
\text { bio-oil or } \\
\text { HTL } \\
\text { biocrude }\end{array}$ & & Research stage & $\begin{array}{l}\text { 1. Miscible with } \\
\text { MGO } \\
\text { 2. Good heating } \\
\text { value }\end{array}$ & Bench scale only & \\
\hline $\begin{array}{l}\text { HFO } \\
\text { baseline }\end{array}$ & $\begin{array}{l}\text { Petroleum } \\
\text { crude }\end{array}$ & Commercial & $\begin{array}{l}\text { 1. Low-cost } \\
\text { 2. Mature } \\
\text { technology } \\
\text { 3. Existing } \\
\text { infrastructure }\end{array}$ & $\begin{array}{l}\text { 1. High } \mathrm{SO}_{\mathrm{x}} \text { and } \\
\mathrm{PM} \text { emissions } \\
\text { 2. Requires } \\
\text { onboard } \\
\text { processing } \\
\text { 3. Nonrenewable }\end{array}$ & $\begin{array}{l}500,000 \text { barrels } \\
\text { per day }\end{array}$ \\
\hline
\end{tabular}


Table 3. Key fuel properties of selected biofuels for marine use

\begin{tabular}{lcccccc}
\hline \multicolumn{1}{c}{ Property } & Biodiesel & $\begin{array}{c}\text { Renewable } \\
\text { diesel }\end{array}$ & $\begin{array}{c}\text { F-T } \\
\text { diesel }\end{array}$ & $\begin{array}{c}\text { FP } \\
\text { bio-oil } \\
\text { (woody } \\
\text { feeds) }\end{array}$ & $\begin{array}{c}\text { Upgraded } \\
\text { bio-oil }\end{array}$ & $\begin{array}{c}\text { HTL } \\
\text { Biocrude } \\
\text { (woody } \\
\text { feeds) }\end{array}$ \\
\hline Specific gravity & 0.88 & 0.78 & 0.765 & $1.1-1.3$ & 0.84 & 1.1 \\
\hline $\begin{array}{l}\text { Kinematic viscosity }\left(40^{\circ} \mathrm{C}\right), \\
\text { cSt }\end{array}$ & $4-6$ & $2-4$ & 2 & $40-100$ & & \\
\hline Cetane number & $47-65$ & $>70$ & $>70$ & & & \\
\hline Lubricity, $\mu \mathrm{m}$ & & 650 & 371 & & & \\
\hline Lower heating value, $\mathrm{MJ} / \mathrm{kg}$ & 37.2 & 44.1 & 43 & 16 & & \\
\hline Cloud point, ${ }^{\circ} \mathrm{C}$ & $-3-15$ & -5 to -34 & -18 & & & \\
\hline Pour point, ${ }^{\circ} \mathrm{C}$ & $-5-10$ & & & -9 to -36 & & $10-13$ \\
\hline Water content, mass $\%$ & $\mathrm{Nil}$ & $\mathrm{Nil}$ & $\mathrm{Nil}$ & $20-35$ & 0.1 & 0 \\
\hline Oxygen content, mass $\%$ & 11 & 0 & 0 & $34-45$ & 0.5 & \\
\hline Sulfur content, mass $\%$ & $<0.0015$ & $<0.0005$ & $<0.1$ & $0-0.05$ & $<0.005$ & 0 \\
\hline
\end{tabular}

\section{Table 4. Marine fuel properties (place holder from IEA 2016 report; top is} distillate, bottom is HFO) ${ }^{a}$ Specification

\begin{tabular}{|c|c|c|c|c|c|}
\hline \multirow{2}{*}{$\begin{array}{l}\text { Table 4. Marine fuel properties (place } \\
\text { holder from IEA } 2016 \text { report; top is } \\
\text { distillate, bottom is HFO) }{ }^{a} \text { Specification }\end{array}$} & \multicolumn{3}{|c|}{ Marine Gas Oils } & \multicolumn{2}{|c|}{ Heavy Fuel Oils } \\
\hline & DMA & DMZ & DMB & RMG180 & RMG380 \\
\hline Kinematic Viscosity, cSt & $2-6$ & $3-6$ & $2-11$ & 180 & 380 \\
\hline Density at $15^{\circ} \mathrm{C}$ & 890 & 890 & 900 & 991 & 991 \\
\hline Min. Cetane Number & 40 & 40 & 35 & $\mathrm{n} / \mathrm{a}$ & $\mathrm{n} / \mathrm{a}$ \\
\hline Lower Heating Value, $\mathrm{MJ} / \mathrm{kg}$ & 45.6 & 45.6 & 45.6 & 42.3 & 42.4 \\
\hline Max Sulfur, mass $\%$ & 1.5 & 1.5 & 2 & 3.5 & 3.5 \\
\hline TAN, $\mathrm{Mg} \mathrm{kOH} / \mathrm{g}$ & 0.5 & 0.5 & 0.5 & 2.5 & 2.5 \\
\hline Oxygen stability, $\mathrm{g} / \mathrm{m}^{3}$ & 25 & 25 & 25 & $\mathrm{n} / \mathrm{a}$ & $\mathrm{n} / \mathrm{a}$ \\
\hline Lubricity, $\mu \mathrm{m}$ & 520 & 520 & 520 & $\mathrm{n} / \mathrm{a}$ & $\mathrm{n} / \mathrm{a}$ \\
\hline Pour point, ${ }^{\circ} \mathrm{C}$ & $-6-0$ & $-6-0$ & $0-6$ & 30 & 30 \\
\hline Water, volume $\%$ & $\mathrm{n} / \mathrm{a}$ & $\mathrm{n} / \mathrm{a}$ & 0.3 & 0.5 & 0.5 \\
\hline Ash, mass\% & 0.1 & 0.1 & 0.1 & 0.1 & 0.1 \\
\hline
\end{tabular}

${ }^{a}$ Values listed are maximum limits, unless otherwise specified.

Because $\mathrm{HFO}$ is highly viscous at ambient conditions, it must be heated to $\sim 120^{\circ} \mathrm{C}$ to exhibit proper flow for engine use. The fuel handling systems on a ship are complex and take up valuable space. Additional energy and space are needed to remove, handle, and store wastewater and solids. The energy (and subsequent cost) requirements to process HFO are substantial. Despite these costs, it is still more economical to operate on HFO than on marine distillates. The high costs associated with upgrading biooil and producing F-T diesel and renewable diesel preclude their use as marine fuel. Raw bio-oil that is not upgraded is a possibility and has several attractive features such as low viscosity, high levels of oxygenates, and low solids content [Lehto 2013]. One option would be to blend HFO with bio-oil to 
reduce PM and sulfur emissions. The properties of bio-oil and HFO blends are not known, however, and it is recommended that studies be initiated to determine the efficacy of blends on fluid handling, compatibility, combustion efficiency, and emissions. Such studies would need to consider high- and medium-speed diesel engines as well as the large slow-speed crosshead engines currently used to power large container and cargo vessels.

\section{BIOFUEL OPTIONS: ECONOMIC OUTLOOK}

Variation in the estimated cost premium of $0.5 \%$ sulfur fuel depends on several assumptions. One uncertainty is the supply/demand associated with the low-sulfur fuel, which is highly dependent on how many ships install scrubber systems. Lower adoption rates will drive up the demand and associated price of $0.5 \%$ sulfur fuel and result in a higher premium. Other impacts on this cost differential are a result of disagreement on how refiners would meet such low-sulfur requirements. Studies suggest that one option is to shift the fuel mix and potentially shift demand from lower-cost residual fuel oil to distillates by up to 2 million barrels per day. Other estimates suggest that petroleum refiners will limit production of residual oils and focus more on road fuels, which would again reduce supply and drive up costs. Options include installation of a hydrotreating process that would help meet the lower sulfur level but would require capital investment. Additionally, the hydrotreating units require significant additional hydrogen, which will likely increase demand beyond the capacity of many current suppliers and will have implications for greenhouse gas (GHG) emissions. The strategy on how to produce low-sulfur marine fuels will be refinery specific and will vary based on the potential value proposition for each refinery [IHS 2017].

The future deployment and price for these fuels is highly dependent on the market and is clearly driven by supply/demand considerations. Estimations of the potential price differential between the $0.5 \%$ and $3.5 \%$ sulfur fuels are highly uncertain. A key objective in this effort is to identify a potential minimum selling price for the biofuel blend stocks that is comparable with the projected cost of low-sulfur marine fuels. Rather than consider these highly uncertain cost projections, we have referred to prior cost differentials seen between $1 \%$ and 3.5\% sulfur fuels. Per estimates by Platts, "During this five-year period, the premium of FOB Northwest Europe 1\% sulfur fuel oil cargoes over 3.5\% FOB Rotterdam barges averaged $\$ 24.95 / \mathrm{mt}$. Linearly, this gives $\$ 0.998 / \mathrm{mt}$ per $0.1 \%$ of sulfur, which would imply a $\$ 30 / \mathrm{mt}$ premium of $0.5 \%$ over $3.50 \%$ as a very rough starting point" [Platts 2016]. Applying this $\$ 30 /$ metric ton premium and considering a range of fuel oil prices, Table 5 summarizes the potential allowable price of biofuels if we assume near-linear blending. Table 6 shows the current price levels of biofuel types.

Table 5. Potential minimum biofuel blendstock value to be comparable with projected cost of low-sulfur marine fuels

\begin{tabular}{ccc}
\hline $\begin{array}{c}\text { Targeted fuel oil } \\
\text { price (\$/gal) }\end{array}$ & $\begin{array}{c}\text { Estimated price required for bio- } \\
\text { blendstock (\$/gal) }\end{array}$ & $\begin{array}{c}\text { Estimated price required for bio-blendstock } \\
\text { (\$/gal) 20/80 split of bio to fossil }\end{array}$ \\
\hline 3 & 3.1 & 3.6 \\
\hline 2 & 2.1 & 2.6 \\
\hline 1.5 & 1.6 & 2.1 \\
\hline
\end{tabular}


Table 6. Preliminary biofuels pricing

\begin{tabular}{|c|c|c|}
\hline Fuel & \$/gallon & Notes \\
\hline $\begin{array}{l}\text { Bio-diesel (fatty acid } \\
\text { methyl esters) }\end{array}$ & $\$ 3-\$ 3.5$ (EIA 2016) & $\begin{array}{l}\text { B20 \$0.19<diesel currently per EIA blending study: } \\
\text { Fuel Proc Tech } 2010 \text { 122:91-97 }\end{array}$ \\
\hline \multicolumn{3}{|l|}{$\mathrm{SVO}$} \\
\hline Renewable diesel & $\begin{array}{l}\text { \$3-\$4.30/gal depending on } \\
\text { feedstock cost }\end{array}$ & $\begin{array}{l}\text { Characteristics and stability, Fuel (2019) 236:516- } \\
524 \text {, for representative type of HRD-76 }\end{array}$ \\
\hline F-T diesel () & $\$ 1.2-\$ 3.1$ & $\begin{array}{l}\text { Low end } 100 \% \mathrm{NG} \text { at } \$ 3 / \mathrm{mmbtu} \\
\text { High end at } 100 \% \text { biomass at } \$ 60 / \text { dry ton }\end{array}$ \\
\hline FP bio-oil & $\begin{array}{l}\sim \$ 0.94-\text { might be lower } \\
\text { depending on feedstock } \\
\text { price and availability }\end{array}$ & $\begin{array}{l}\text { \$84/ton; } 2000 \text { mtpd biomass; } 70-85 \% \text { yield on } \\
\text { biomass; blending study: Env Prog \& Sus Energy } \\
2017 \text { 36(3):677-684; biomass quality can be } \\
\text { important (e.g., low ash increases oil yield) }\end{array}$ \\
\hline $\begin{array}{l}\text { Upgraded bio-oil }(<2 \\
\text { wt } \% \text { oxygen })\end{array}$ & $\sim \$ 3.7$ - not yet commercial & $\begin{array}{l}\$ 84 / \text { ton; } 2000 \mathrm{mtpd} \text { biomass; } 27 \mathrm{wt} \% \text { yield; might } \\
\text { need to correct initial and final boiling point; biomass } \\
\text { quality (e.g., high ash) can negatively affect yield }\end{array}$ \\
\hline $\begin{array}{l}\text { Hydrothermal } \\
\text { liquefaction }\end{array}$ & $\begin{array}{l}\sim \$ 2-\$ 2.4-\text { not yet } \\
\text { commercial }\end{array}$ & $\begin{array}{l}\$ 60 / \text { ton; } 2000 \mathrm{mtpd} \text { biomass; } 30-36 \mathrm{wt} \% \text { yield; can } \\
\text { use lower quality, less expensive feedstock (e.g., high } \\
\text { ash) }\end{array}$ \\
\hline
\end{tabular}

\section{ENVIRONMENTAL BENEFITS}

A driver for the use of biofuels for marine applications is the potential to reduce emissions of $\mathrm{SO}_{\mathrm{x}}, \mathrm{NO}_{\mathrm{x}}$, and PM, resulting in improved air quality globally and in particular in and near harbors, compared with the use of heavy fuel oil or marine diesel. Using high-resolution emissions inventories, Sofiev and colleagues [Sofiev et al. 2018] estimate that proposed standards limiting sulfur in fuel oil to $0.5 \%$ by mass would reduce $\mathrm{PM}_{2.5}$-related cardiovascular and lung cancer deaths globally by $\sim 2.6 \%$ and would reduce childhood asthma by $\sim 3.6 \%$. The biofuel options previously described have naturally very low sulfur content and have the potential to provide additional environmental benefits when compared with lowsulfur fuel oil or marine distillate.

The HFO currently used for marine applications emits large amounts of criteria air pollutants, including $\mathrm{SO}_{\mathrm{x}}, \mathrm{NO}_{\mathrm{x}}$, and $\mathrm{PM}$ amongst others, when compared with other drop-in fuel alternatives. Figure provides the emissions of greenhouse gases and selected air pollutants, as well as fossil fuel use, associated with residual oil and marine distillates used for marine applications based on Argonne's GREET 2018 marine transportation module. Note that WTP stands for well-to-pump and PTH stands for pump-to-hull. Emissions of low-sulfur marine distillate are also shown in cases where they differ from conventional marine distillate. Although marine distillate and low-sulfur marine distillate have the potential to reduce sulfur oxide, PM, and black carbon emissions, marine distillate emits amounts of other pollutants of interest such as $\mathrm{CO}_{2}$ and $\mathrm{NO}_{\mathrm{x}}$ at levels similar to those of HFO. As do residual oils, marine distillates rely on fossil resources to produce energy. 


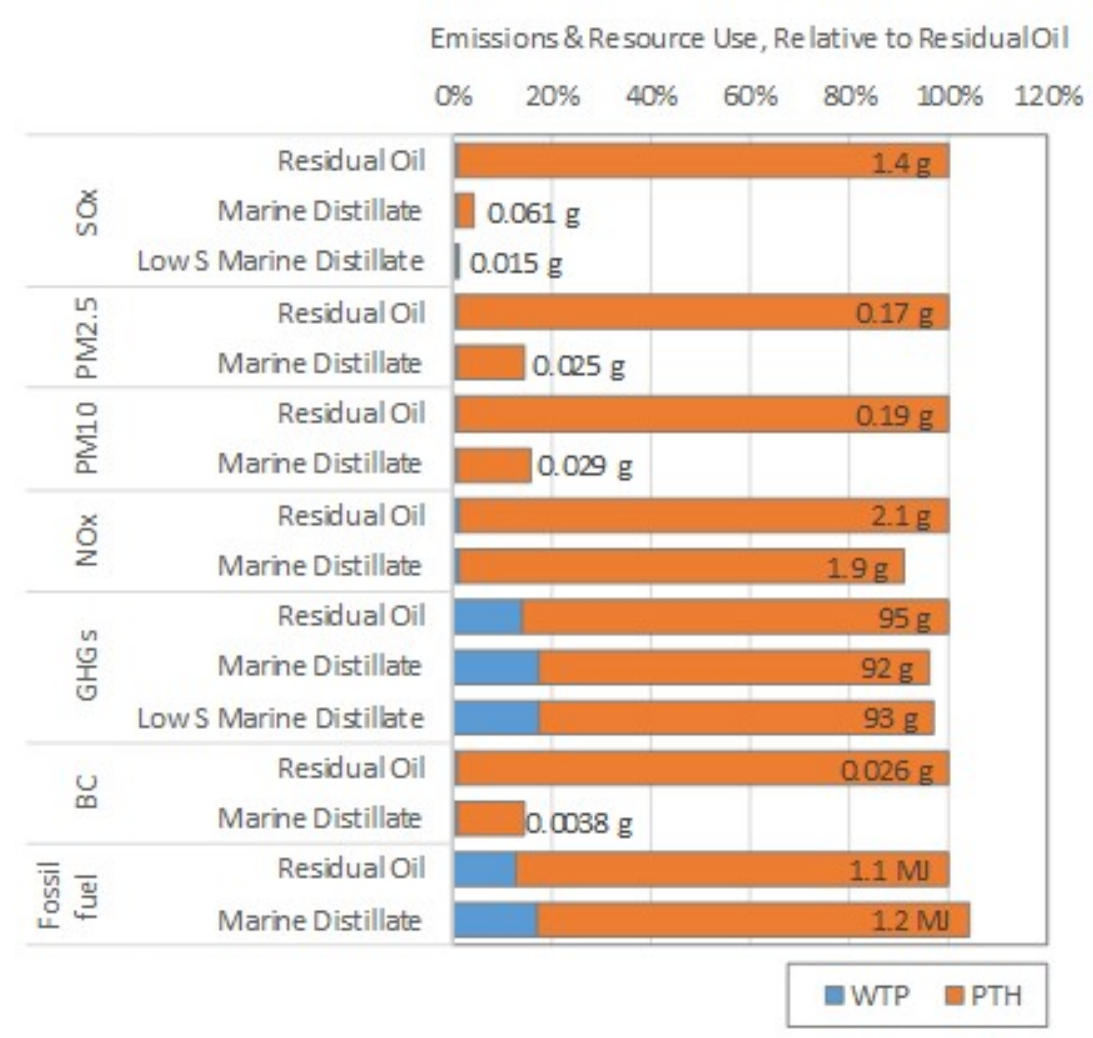

Figure 2. Emissions and resource use associated with the use of HFO (residual oil) and marine distillate.

To allow display of multiple metrics, amounts are shown relative to the amount for residual oil. The values displayed on each bar reflect the emissions and fossil fuel use per megajoule of fuel combusted. Sulfur content is based on GREET 2018 defaults - percent by mass: $2.7 \%$ for residual oil (as a surrogate for HFO), $0.10 \%$ for marine distillate, and $0.0011 \%$ for low-sulfur marine distillate.

Biofuels inherently have very low sulfur content, which translates to low $\mathrm{SO}_{\mathrm{x}}$ emissions on combustion. As described previously, $\mathrm{SO}_{\mathrm{x}}$ is a precursor to secondary particulate matter formation; thus, the biofuels considered here have the potential to offer significant human health benefits when compared with conventional marine fuels. Figure a provides the GREET 2018 estimates of the life-cycle $\mathrm{SO}_{\mathrm{x}}$ emissions for biofuel alternatives to conventional marine fuels. These biofuels offer drastic reductions in $\mathrm{SO}_{\mathrm{x}}$ emissions (and consequently secondary PM) compared with residual oil. And although $\mathrm{SO}_{\mathrm{x}}$ emissions from marine distillate are already much lower than those for residual oil fuels, the biofuel options still offer significant reductions compared with marine distillate and are in fact comparable with those of lowsulfur marine distillate.

Although biofuels have the potential to reduce $\mathrm{SO}_{\mathrm{x}}$ emissions in marine applications, further research is needed to characterize other environmental impacts such as emissions of greenhouse gases and other criteria air pollutants and consumption of water and fossil fuels. A tradeoff associated with reducing $\mathrm{SO}_{\mathrm{x}}$ is that it causes a roughly $3 \%$ increase in man-made radiative forcing. This is because the aerosols caused by the sulfur emissions reflect light and promote cloud formation. Sofiev and colleagues (2018) report this effect and emphasize the importance of seeking solutions that simultaneously address PM and climate objectives. Figure b provides the GREET 2018 estimates of GHG emissions for biofuel options compared with conventional alternatives. An advantage of biofuels is that the carbon emitted on combustion was pulled from the atmosphere during the growth of the biomass used to produce them. As can be seen from Figure $3 b$, carbon uptake during biomass growth results in net negative well-to-pump GHG emissions. 
Here the feedstock for the hydrotreated renewable diesel and biodiesel pathways is soybean, and the feedstock for the F-T diesel pathway is forest residue.

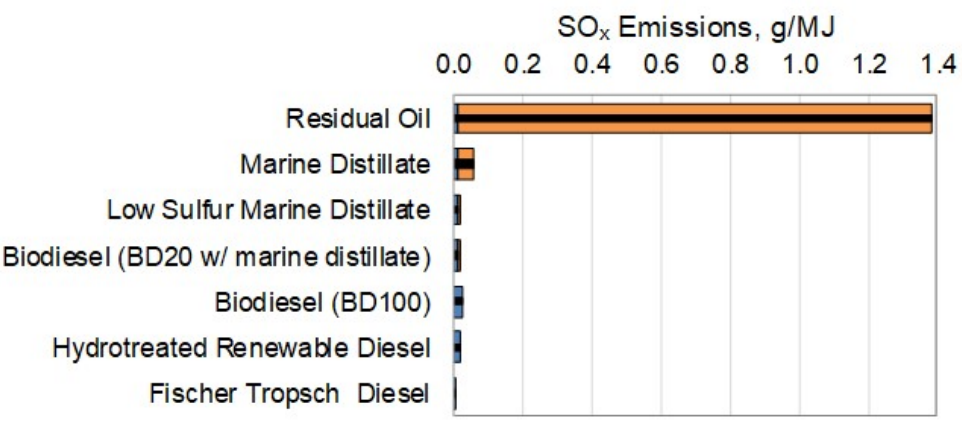

(a)

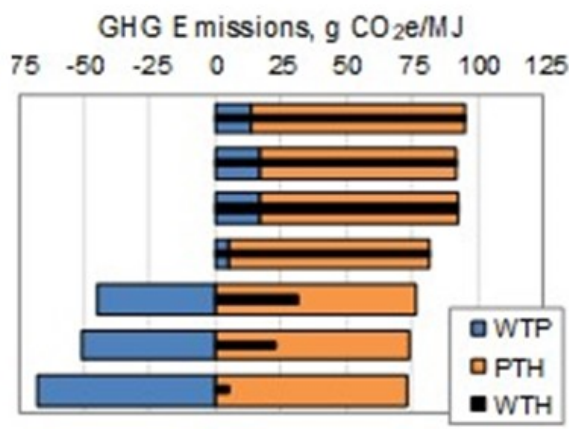

(b)

Figure 3. "Well-to-hull" life cycle $\mathrm{SO}_{\mathrm{x}}(\mathrm{a})$ and GHG (b) emissions per megajoule of fuel combusted for marine applications (the negative values for blue bars reflect carbon uptake during biomass growth). WTP, PTH and WTH stand for well-to-pump, pump-to-hull, and well-to-hull, respectively.

Even while considering the benefits of reducing sulfur content in marine fuels, their combustion will still result in 250,000 deaths and $\sim 6.4$ million childhood asthma cases annually [Sofiev 2018]. Alternative fuels such as well-designed biofuel pathways or LNG have the potential to offer significant benefits for human health and ecosystem quality.

There are several other key benefits of expanded biofuel use. In addition to the environmental and energy benefits presented in Section 7, as an HFO substitute or blending agent, the lower viscosity of biofuels compared with HFO means that the energy requirements needed to heat HFO to achieve proper rheology can be lowered. Reducing the overall viscosity would reduce the energy requirements needed to heat and process HFO before fuel injection. As a result, biofuel offers a way to improve the overall energy efficiency (and $\mathrm{CO}_{2}$ emissions) of vessels, thereby providing a pathway toward meeting future EEDI reduction targets.

Argonne's GREET model includes much of the data required to characterize biofuel pathways for marine applications. Additional research to expand the GREET Marine Transportation modules to include additional biofuel and LNG pathways and to address emerging issues would provide timely insights at a critical moment for maritime policy.

\section{R\&D CHALLENGES, OPPORTUNITIES, AND RECOMMENDATIONS ASSOCIATED WITH BIOFUELS, ESPECIALLY BIO-OIL AS A MARINE FUEL}

Since the primary polluting emissions from marine vessels originate with the combustion of HFO, we recommend examining the impact of low-cost biofuel candidates and biofuel-HFO blends for marine applications. Bio-oil shows significant potential in this application as an HFO substitute and is emphasized in the proposed research program. However, we also recommended other biofuel types be examined for cost and efficacy as marine fuels. $R \& D$ challenges for biofuel use as a marine fuel can be categorized as follows: 
- Elucidation of the combustion characteristics of biofuels, especially bio-oil and its blends with $\mathrm{HFO}$, to ensure proper engine operation. One outcome of this effort is to determine what level of engine modifications are necessary for optimal combustion and operation. Like many oxygenated biofuels, bio-oil has a lower energy content than HFO. This will require calibration of engine operation to ensure that proper power levels and overall performance are maintained.

- Compatibility with HFO to ensure that a selected biofuel is fully miscible with HFO. This effort would seek to understand the rheology of bio-oil and its blends with HFO at elevated temperatures. The information gained from this study will be used to determine the efficacy of these fuels with the existing HFO processing systems. Important parameters include (1) understanding the kinetics and chemistry associated with bio-oil polymerization, (2) the impact on precipitate formation and heavy component settling, (3) solubility and solvency of bio-oil with HFO, and (4) the impact of bio-oil oxygenates and entrained water on current separation systems.

- Compatibility of a selected biofuel, especially bio-oil, which has known compatibility issues, with fuel handling infrastructure to ensure that steel components are not aggressively corroded and that polymer swell is within guidelines.

- Measurement and modeling of the emissions of PM, NOx, and other GHGs to better understand combustion and to ensure that a selected biofuel does not exacerbate air pollution. The presence of oxygenates indicates that PM emissions will be reduced, but this effect needs confirmation. Efficiency and $\mathrm{CO}_{2}$ emissions are important since ships are now required to meet EEDI reductions based on $\mathrm{CO}_{2}$ output.

- Determination of the lubricity of biofuels and blends with HFO to ensure proper engine durability and to guide the development of lubrication packages, which are especially critical for 2-stroke crosshead engines.

- The effects of biofuels (and their blends) on engine fuel injection equipment operation, particularly the fuel spray characteristics as they relate to the combustion and lubrication system (wall wetting from overpenetration). The viscosity and surface tension variations affect the fuel break up and cylinder penetration, as well as the energy density affecting the injection duration and spray targeting in the combustion chamber.

- Improved understanding of the costs, environmental outcomes, and market considerations associated with the various alternative marine fuels and emissions abatement technologies. Crosscutting techno-economic analysis and life-cycle analysis studies would address economic, environmental, and energy considerations for options being developed by and for the marine transport industry. This work would include biofuels in general and bio-oil in particular for marine applications by modeling the supply chain and would use logistics of biofuels and petroleum marine fuel options. A transition to biofuels for marine transport requires global availability and distribution infrastructure; therefore, systems assessment including technoeconomic analysis and life-cycle analysis should address the feedstocks and supply chains/logistics of fuels provided at major ports worldwide.

- Evaluation of biofuels heavier than distillates/diesel as fuels for large low- and medium-speed diesels. A key barrier is the lack of sufficient quantities of some biofuels for large-scale experimentation. The combustion properties of bio-oils are adequate for burner/boiler applications, but they need to be further examined for traditional 2- and 4-stroke diesel operation and 2-stroke crosshead operation. The impact of blending and blend levels needs to be determined. As a diesel or MGO substitute, the cetane number of bio-oils is too low for unmodified engine operation in conventional 2- and 4-stroke diesel engines and might not be recommended without a certain level of upgrading. As a heavy fuel substitute, bio-oil needs to have comparable combustion properties with HFO, which are indicated by the calculated ignition index and the calculated carbon aromaticity index. Both are determined by density and kinematic viscosity of the fuel. For bio-oils, these parameters need to be measured at elevated temperatures, which is a key research need as a function of blend level, feedstock type, and time. The 
polymerization characteristics of bio-oils at elevated temperatures and blends with HFO need to be determined for efficacy with HFO handling systems.

\section{REFERENCES}

BP (British Petroleum). 2018. BP Statistical Review of World Energy, 67th Edition.

DNV GL. 2018. “Current Price Development Oil and Gas.” Accessed December 2018. https://www.dnvgl.com/maritime/lng/current-price-development-oil-and-gas.html.

EPA (US Environmental Protection Agency). 2009. Costs of emission Reduction Technologies for Category 3 Marine Engines: Final Report. EPA-420-R-09-008. https://nepis.epa.gov/Exe/ZyPDF.cgi/P100GPCR.PDF?Dockey=P100GPCR.PDF.

ICCT (International Council on Clean Transportation). 2011. The energy efficiency design index (EEDI) for new ships. The International Council on Clean Transportation. Policy Update 15.

IHS. 2017. "Refining and Shipping Industries Will Scramble to Meet the 2020 IMO Bunker Fuel Rules." IHS Markit. https://ihsmarkit.com/Info/0817/refining-and-shippingimo.html?utm medium=print\&utm_source=pressrelease\&utm_campaign=PC9992.

IMO (International Maritime Organization). 2016. "Train the Trainer (TTT) Course on Energy Efficient Ship Operation.” Module 2: Ship Energy Efficiency Regulations and Related Guidelines. http://www.imo.org/en/OurWork/Environment/PollutionPrevention/AirPollution/Documents/Air\%20 pollution/IMO\%20Train\%20the\%20Trainer\%20Course.pdf.

IMO. 2015. Investigation of Appropriate Control Measures (Abatement Technologies) to Reduce Black Carbon Emissions from Marine Shipping: Study Report.

ISO. 2010. International Standard ISO 8217:2010 (E) Petroleum Products - Fuels (Class F) Specifications of marine fuels.

Lehto, J., A. Oasmaa, Y. Solantausta, M. Kyto, and M. Chiaramonti. 2013. Fuel oil quality and combustion of fast pyrolysis bio-oils. VTT Technology 87, VTT. Finland: Julkaisija-Utgivare.

Pearce, F. 2009. "How 16 ships create as much pollution as all the cars in the world," Daily Mail.com https://www.dailymail.co.uk/sciencetech/article-1229857/How-16-ships-create-pollution-carsworld.html.

Platts. 2016. The IMO's 2020 Global Sulfur Cap: What a 2020 Sulfur-constrained world means for shipping lines, Refineries and Bunker Suppliers. Shipping Special Report. S\&P Global. https://www.platts.com/IM.Platts.Content/InsightAnalysis/IndustrySolutionPapers/SR-IMO-2020Global-sulfur-cap-102016.pdf.

Sofiev, M., et al. 2018. "Cleaner Fuels for Ships Provide Public Health Benefits with Climate Tradeoffs." Nature Communications 9, Article number 406. DOI: 10.1038/s41467-017-02774-9.

Walker, S. 2017. “A Multi-fuel Future: The Impact of the IMO Sulfur Cap.” ExxonMobil presentation deliveredat Oak Ridge National Laboratory.

Wiesmann, A. 2010. "Slow Steaming - A Viable Long-term Option?" Wartsila Technical Journal. https://www.wartsila.com/docs/default-source/Service-catalogue-files/Engine-Services---2stroke/slow-steaming-a-viable-long-term-option.pdf. 